\title{
Association between interleukin-6 polymorphisms and urinary system cancer risk: evidence from a meta-analysis
}

This article was published in the following Dove Press journal:

OncoTargets and Therapy

27 January 2016

Number of times this article has been viewed

\author{
Kaiping Zhang* \\ Li Zhang* \\ Jun Zhou \\ Zongyao Hao \\ Song Fan \\ Cheng Yang \\ Chaozhao Liang
}

Department of Urology, The First Affiliated Hospital of Anhui Medical University and Institute of Urology, Anhui Medical University, Hefei, Anhui, People's Republic of China

*These authors contributed equally to this work
Correspondence: Chaozhao Liang; Li Zhang

Department of Urology, The First Affiliated Hospital of Anhui Medical University and Institute of Urology, Anhui Medical University, No 218 Jixi Road, Hefei 230022, Anhui, People's Republic of China Tel +86 55I 6292386I; +8655I 62923932

Email liangchaozhao@163.com; Izhang_nanomed@|63.com
Background: Interleukin-6 (IL-O) is a multifunctional proinflammatory cytokine involved in cancer initiation and progression. Numerous studies have investigated the associations between $I L-6$ polymorphisms ( $I L-6-174 \mathrm{G}>\mathrm{C},-592 \mathrm{G}>\mathrm{C},-597 \mathrm{G}>\mathrm{A})$ and risk of urinary system cancers, including prostate cancer, bladder cancer, and renal cell cancer. However, conclusions from these studies were controversial. Thus, we conducted the current meta-analysis to obtain the comprehensive profile regarding the association between $I L-6$ polymorphisms and urinary system cancer risk.

Methods: According to inclusion and exclusion criteria, the associations of $I L-6$ polymorphisms with urinary system cancer were searched from database and analyzed using STATA 12.0 statistical software. Odds ratios (ORs) with 95\% confidence intervals (CIs) were used to assess the strength of the associations.

Results: A total of 20 previous publications consisting of 15,033 cases and 17,655 controls were involved in this meta-analysis. Significant association was observed in overall population regarding $I L-6-592 \mathrm{G}>\mathrm{C}$ polymorphisms $(\mathrm{G}$ vs $\mathrm{C}$ : $\mathrm{OR}=0.1 .30,95 \% \mathrm{CI}=1.13-2.52$; $\mathrm{GG}$ vs $\mathrm{CC}: \mathrm{OR}=1.81,95 \% \mathrm{CI}=1.31-2.52 ; \mathrm{GG}$ vs $\mathrm{GC}+\mathrm{CC}: \mathrm{OR}=1.33,95 \% \mathrm{CI}=1.02-1.75 ; \mathrm{GG}+$ $\mathrm{GC}$ vs $\mathrm{CC}: \mathrm{OR}=1.41,95 \% \mathrm{CI}=1.09-1.83)$. In the stratified analyses by ethnicity, the significant associations were found among Asian (GG vs CC: OR $=1.89,95 \% \mathrm{CI}=1.34-2.66$; GG + $\mathrm{GC}$ vs $\mathrm{CC}: \mathrm{OR}=1.43,95 \% \mathrm{CI}=1.09-1.87$ ) and Black population (GC vs CC: $\mathrm{OR}=0.20,95 \%$ $\mathrm{CI}=0.05-0.82)$ rather than Caucasian men. Likewise, there were noticeable associations in almost all the other subanalyses such as cancer types, control sources, genotyped methods, and sample sizes. However, no significant associations were identified between any of $I L-6-174 \mathrm{G}>\mathrm{C}$ polymorphisms with urinary system cancer, except for Asian population ( $\mathrm{G}$ vs $\mathrm{C}$ : $\mathrm{OR}=0.81$, 95\% CI $=0.70-0.95 ;$ GG vs CC: $\mathrm{OR}=0.51,95 \% \mathrm{CI}=0.35-0.74 ; \mathrm{GC}$ vs CC: $\mathrm{OR}=0.49,95 \%$ $\mathrm{CI}=0.33-0.72 ; \mathrm{GG}+\mathrm{GC}$ vs $\mathrm{CC}: \mathrm{OR}=0.50,95 \% \mathrm{CI}=0.35-0.72$; respectively). In addition, no significant associations were detected between $I L-6-597 \mathrm{G}>$ A polymorphism and urinary system cancer, regardless of whole or subgroups.

Conclusion: This meta-analysis presents a relatively comprehensive view of the associations between $I L-6$ polymorphism and urinary system cancer risk to explore the carcinogenic mechanisms, which will help shed light on the clinical diagnosis and therapy for urinary system cancer. However, further detailed studies are needed to verify our conclusion.

Keywords: $I L-6$, polymorphism, urinary system cancer, risk, inflammation, meta-analysis

\section{Introduction}

Cancer has become a challenging problem which severely threatens public health. There has been a progressive increase in the incidence and mortality of urinary system cancer, which has drawn extensive attention in clinic. Most recent cancer statistics in 
2015 by the American Cancer Society have estimated that the incidence of prostate cancer (PCa) is still top-ranked (26\%) in men, which is significantly more than that of any other cancer types, including lung cancer or colorectal cancer. Meanwhile, bladder cancer (BCa, 7\%) and renal cell cancer ( $\mathrm{RCC}, 5 \%$ ) are in fourth and seventh place, respectively. Correspondingly, $\mathrm{PCa}$ is the second leading cause of male cancer-related deaths, with approximately 220,800 deaths calculated in the USA. BCa (4\%) and RCC (3\%) are in eighth and tenth place, respectively. ${ }^{1}$ The mechanism of carcinogenesis is still largely unexplored. During the past decades, apart from genetic mutations that have raised major concerns about cancer in clinical practice, the role of inflammation has also been recognized as an arresting risk factor in the etiology of cancer. So far, definite causal relationships have been established between gastric cancer and Helicobacter pylori, colon cancer and inflammatory bowel disease. ${ }^{2}$ More importantly, substantial evidences suggest a possible risk factor for chronic inflammation in urinary system cancer such as $\mathrm{PCa}$ and prostatitis, ${ }^{3} \mathrm{BCa}$ and schistosomiasis, ${ }^{4} \mathrm{RCC}$ and nephritis. ${ }^{5}$

Molecular mechanisms underlying inflammationassociated cancer include DNA damage, ${ }^{6}$ disruption of the immune response, and alternation of the tumor microenvironment, ${ }^{7}$ which are all closely related to disequilibrium of inflammatory cytokines. IL-6 is a cancerassociated multifunctional proinflammatory cytokine produced by activated T-cells, B-cells, monocytes, as well as cancerous cells. The $I L-6$ gene, located at chromosome 7p21-24, is composed of four introns and five exons. Since single nucleotide polymorphisms (SNPs) of $I L-6$ gene promoter may affect the expression and secretion of IL-6, and subsequently the altered circulating levels might result in relevant biological responses, the $I L-6$ polymorphism has been regarded as a crucial modulator in pathogenesis of various cancer types, including breast cancer, ${ }^{8}$ colorectal cancer, ${ }^{9}$ hepatocellular carcinoma, ${ }^{10}$ and so on. Notably, although several studies have shown that $I L-6$ polymorphisms could be involved in the development of urinary system cancer, the conclusions were not consistent. ${ }^{11-13}$ The probable reasons may be the relatively small cohort size in each published study. Meta-analysis primarily focuses on comparing and integrating results from individual investigations to provide a relatively precise and accurate estimation, which can explore the authentic and comprehensive effects via statistical analyses. ${ }^{14}$ Herein, we conducted the updated meta-analysis to evaluate the associations between $I L-6$ polymorphisms and urinary system cancer risk.

\section{Materials and methods Identification and eligibility of relevant studies}

For the study, we searched the following widely used electronic literature databases: PubMed, Embase, China Biology Medicine disc, and China National Knowledge Infrastructure, for the following terms: "interleukin6 or interleukin-6 or IL-6 or IL6", "prostate cancer", "bladder cancer", "renal cell cancer", "urinary system cancer", and "polymorphism or polymorphisms". The last search was updated on June 5, 2015. No language restrictions were performed in this meta-analysis. All retrieved articles and reviews were searched to identify other relevant publications. When the different ethnicities appeared in a reported article, we treated them independently.

\section{Inclusion criteria}

The relevant studies in meta-analysis were included using the following criteria: 1) studies that were case-control or cohort studies; 2) studies that performed the associations between IL-6 polymorphisms and urinary system cancer risk and acquired sufficient information for odds ratios (ORs) and their 95\% confidence intervals (CIs); and 3 ) urinary system cancers were histologically confirmed in case group. Studies were considered unqualified if they met the following criteria: 1) no data regarding associations between $I L-6$ polymorphisms and urinary system cancer risk; 2) duplicate of previous publication (when the same cohort was used in several publications, only the most complete information was included after careful examination); and 3) reviews or abstracts.

\section{Data extraction}

The information was independently extracted from each eligible publication with inclusion and exclusion criteria by two authors. If there were disagreements, we resolved it through a discussion (K Zhang and L Zhang), or got it reviewed by a third author (J Zhou).

The following information was collected from each study: first author, year of publication, study country, race, genotyped method, study design, polymorphisms, the number of case and control, the type of cancer, and $P$-value of Hardy-Weinberg equilibrium (HWE) in control. The quality of each included study was evaluated by the NewcastleOttawa Scale, including selection of groups, comparability of the group, and ascertainment of exposure. The NewcastleOttawa Scale scores ranged from 0 to 10 stars. A study awarded seven or more stars was regarded as a high-quality study. ${ }^{15}$ We did not contact the corresponding author even 
if primary genotype frequency information was unavailable. Subsequently, we classified the urinary system cancer as PCa, $\mathrm{BCa}$, and RCC. Ethnicity was stratified into three groups: Caucasian, Black, and Asian population. If the studies did not explain or separate the source of ethnicity, we named it as "mixed". Study designs were defined as hospital-based and population-based studies. Genetyped methods were divided into TaqMan, polymerase chain reaction (PCR), or others, including PCR-restriction fragment length polymorphism, PCR-sequence-specific primer, Massarray, GoldenGate, and sequencing.

\section{Statistical analysis}

We explored the relationship of $I L-6$ polymorphisms and risk to urinary system cancer using STATA version 12.0 (StataCorp LP, College Station, TX, USA). OR and 95\% CI were used to estimate the strength of relationship between $I L-6$ polymorphisms and the susceptibility to cancer. We determined the associations with cancer risk underlying genotyping models, including allele comparison, recessive model, dominant model, homozygote model, and heterozygote model. Meanwhile, test of heterogeneity was measured by the chi-square-based Q test and the $I^{2}$ test $\left(I^{2}<25 \%\right.$ no heterogeneity, $25 \% \leq I^{2} \leq 50 \%$ moderate heterogeneity, $I^{2}>50 \%$ extreme heterogeneity). ${ }^{16}$ If $I^{2}>50 \%$ or $P<0.10$ for the $\mathrm{Q}$ test, the heterogeneity of studies was considered statistically significant. As a result, the pooled OR estimation of study was calculated by the random-effects (DerSimonian and Laird method) model; ${ }^{17}$ otherwise, the fixed-effects (Mantel and Haenszel method) model was introduced..$^{18}$

The stability of the results was assessed by applying one-way sensitivity analyses, which individually removed studies in meta-analysis to explore the impact of each study on the pooled OR.

Potential publication biases were assessed by the Begg's funnel plots in which the log OR was plotted against its standard error. $P<0.05$ by Begg's funnel plots was considered as a statistically significant publication bias. ${ }^{19}$ Additionally, we subclassified studies into different subgroups, including cancer type, ethnicity, source of control, genotyped method, and sample size.

\section{Results}

\section{Characteristics of eligible studies}

According to inclusion and exclusion criteria, a total of 17 studies with 15,033 cases and 17,655 controls satisfied the eligible studies. ${ }^{11-13,20-33}$ Three eligible publications investigated two different ethnicities and we independently separated them into meta-analysis. Therefore, this updated meta-analysis was established based on 20 studies (Figure 1). Of the 20 studies, three $I L-6$ polymorphisms were reported $(-174 \mathrm{G}>\mathrm{C} ;-592 \mathrm{G}>\mathrm{C}$; and $-597 \mathrm{G}>\mathrm{A})$ and eleven Caucasian, three Black, and six Asian population were estimated. Among the cancer types, 15, three, and two studies were related to $\mathrm{PCa}, \mathrm{BCa}$, and $\mathrm{RCC}$, respectively.

Of the 20 studies, 19 were written in English and one was published in Chinese. The sample sizes ranged from 72 to 16,445. Meanwhile, nine TaqMan, five PCR, and six others in genotyped methods were applied. According to the source of control, seven were hospital-based and 13 were populationbased as controls. The results of HWE test in control were calculated in eligible studies. All cancerous specimens were histologically confirmed. The characteristics of studies investigating the associations of $I L-6$ polymorphisms with urinary system cancer are shown in Table 1.

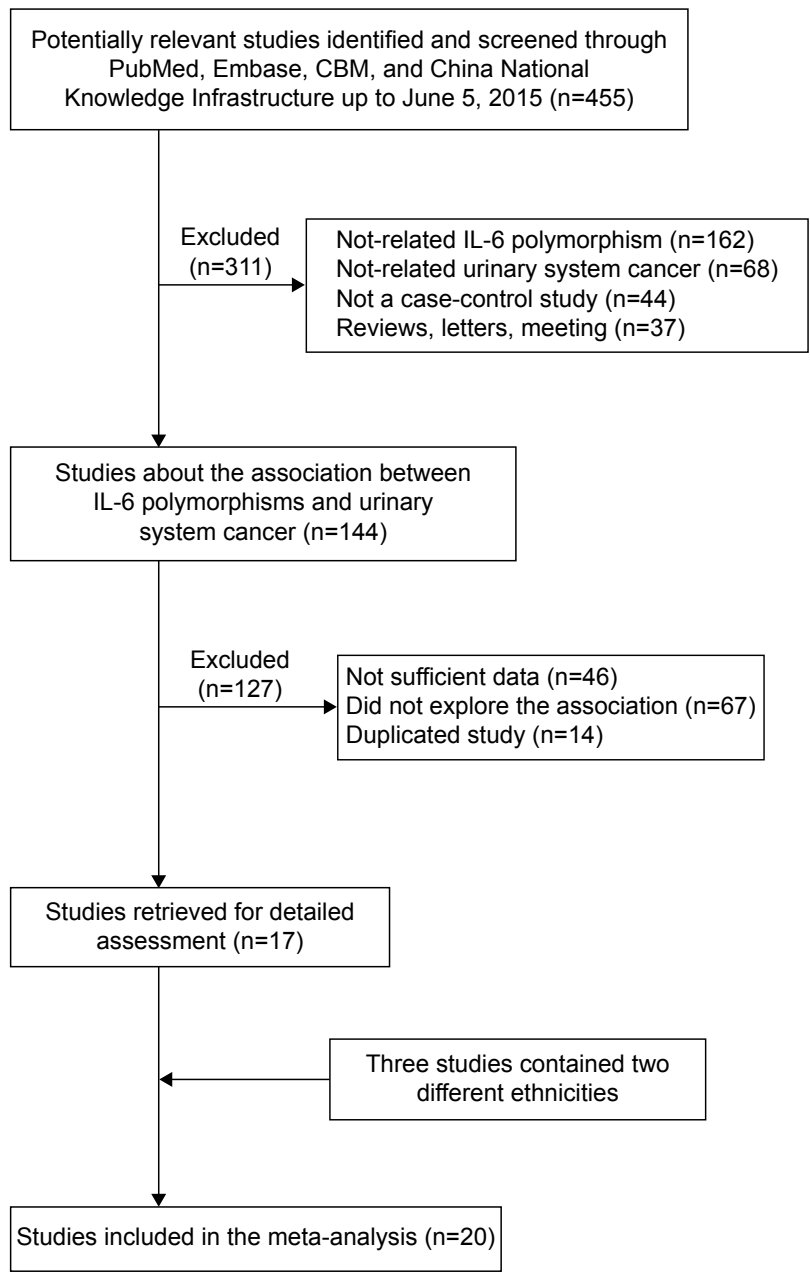

Figure I Flow diagram of the inclusion and exclusion of studies. Abbreviations: CBM, China Biology Medicine disc; IL, interleukin. 
Table I Characteristics of the eligible studies in this meta-analysis

\begin{tabular}{|c|c|c|c|c|c|c|c|c|c|c|}
\hline $\begin{array}{l}\text { First } \\
\text { author }\end{array}$ & Year & Country & Ethnicity & Cancer type & $\begin{array}{l}\text { Genotyped } \\
\text { method }\end{array}$ & Design & Polymorphisms & Case/control & HWE & NOS \\
\hline Mandal & 2014 & USA & Caucasian & Prostate & PCR & PB & $-174 G>C$ & $84 / 78$ & 0.043 & 9 \\
\hline et $\mathrm{a}^{26}$ & & & Black & Prostate & PCR & PB & $-174 G>C$ & $80 / 62$ & 0.316 & \\
\hline $\begin{array}{l}\text { Moore } \\
\text { et } \mathrm{a}^{28}\end{array}$ & 2009 & Finland & Caucasian & Prostate & TaqMan & PB & $-174 G>C$ & $\mathrm{I}, 04 \mathrm{I} / \mathrm{I}, 048$ & 0.152 & 8 \\
\hline $\begin{array}{l}\text { Kesarwani } \\
\text { et } \mathrm{a}^{23}\end{array}$ & 2008 & India & Asian & Prostate & PCR & $\mathrm{HB}$ & $-174 G>C$ & $200 / 200$ & 0.120 & 8 \\
\hline Lu et $\mathrm{a}^{25}$ & 2011 & $\begin{array}{l}\text { People's } \\
\text { Republic } \\
\text { of China }\end{array}$ & Asian & Prostate & PCR-RFLP & $\mathrm{HB}$ & $-592 G>C$ & $200 / 279$ & 0.051 & 7 \\
\hline \multirow[t]{2}{*}{ Wang et $\mathrm{al}^{31}$} & 2009 & USA & Caucasian & Prostate & TaqMan & PB & $\begin{array}{l}-I 74 G>C \text { to } \\
-592 G>C\end{array}$ & $258 / 258$ & $0.449 / 0.405$ & 8 \\
\hline & & & & & & & $-597 G>A$ & & 0.866 & \\
\hline \multirow[t]{2}{*}{ Pierce et $\mathrm{al}^{29}$} & 2009 & USA & Caucasian & Prostate & TaqMan & PB & $\begin{array}{l}-174 G>C \text { to } \\
-592 G>C\end{array}$ & $175 / 1,934$ & $0.132 / 0.161$ & 8 \\
\hline & & & Black & Prostate & TaqMan & PB & $\begin{array}{l}-174 G>C \text { to } \\
-592 G>C\end{array}$ & $40 / 300$ & $0.853 / 0.470$ & \\
\hline \multirow[t]{2}{*}{$\begin{array}{l}\text { Zabaleta } \\
\text { et } \mathrm{al}^{32}\end{array}$} & 2009 & USA & Caucasian & Prostate & TaqMan & $\mathrm{HB}$ & $\begin{array}{l}-174 G>C \text { to } \\
-597 G>A\end{array}$ & $74 / 401$ & $0.000 / 0.199$ & 7 \\
\hline & & & Black & Prostate & TaqMan & $\mathrm{HB}$ & $\begin{array}{l}-174 G>C \text { to } \\
-597 G>A\end{array}$ & $15 / 57$ & $0.000 / 0.646$ & \\
\hline Kwon et $\mathrm{al}^{24}$ & 2011 & USA & Caucasian & Prostate & Sequencing & PB & $-174 G>C$ & I,309/I,265 & 0.995 & 9 \\
\hline $\begin{array}{l}\text { Michaud } \\
\text { et } \mathrm{al}^{27}\end{array}$ & 2006 & USA & Caucasian & Prostate & TaqMan & PB & $-174 G>C$ & $484 / 613$ & 0.832 & 8 \\
\hline Sun et $\mathrm{al}^{30}$ & 2004 & Sweden & Caucasian & Prostate & Massarray & PB & $\begin{array}{l}-174 G>C \text { to } \\
-592 G>C \\
-597 G>A\end{array}$ & $|, 345 / 76|$ & $\begin{array}{l}0.492 / 0.211 \\
0.632\end{array}$ & 8 \\
\hline $\begin{array}{l}\text { Dossus } \\
\text { et al" }\end{array}$ & 2010 & Germany & Caucasian & Prostate & GoldenGate & PB & $-174 G>C$ & $7,937 / 8,508$ & 0.000 & 8 \\
\hline Bao et $\mathrm{al}^{20}$ & 2008 & $\begin{array}{l}\text { People's } \\
\text { Republic } \\
\text { of China }\end{array}$ & Asian & Prostate & TaqMan & PB & $-592 G>C$ & $136 / 120$ & 0.000 & 7 \\
\hline Liu et $\mathrm{al}^{13}$ & 2015 & $\begin{array}{l}\text { People's } \\
\text { Republic } \\
\text { of China }\end{array}$ & Asian & Renal & PCR-RFLP & $\mathrm{HB}$ & $\begin{array}{l}-174 G>C \text { to } \\
-592 G>C\end{array}$ & $216 / 216$ & $0.098 / 0.001$ & 8 \\
\hline $\begin{array}{l}\text { Basturk } \\
\text { et } \mathrm{al}^{21}\end{array}$ & 2004 & Turkey & Caucasian & Renal & PCR-SSP & PB & $-174 G>C$ & $25 / 49$ & 0.007 & 9 \\
\hline $\begin{array}{l}\text { Ahirwar } \\
\text { et al }{ }^{33}\end{array}$ & 2008 & India & Asian & Bladder & PCR & PB & $-174 G>C$ & $136 / 200$ & 0.027 & 8 \\
\hline Guey et $\mathrm{a}^{22}$ & 2010 & Spain & Caucasian & Bladder & TaqMan & $\mathrm{HB}$ & $-174 G>C$ & I,017/I,065 & 0.356 & 8 \\
\hline Ebadi et al ${ }^{12}$ & 2014 & Iran & Asian & Bladder & $\mathrm{PCR}$ & $\mathrm{HB}$ & $-174 G>C$ & $261 / 251$ & 0.579 & 8 \\
\hline
\end{tabular}

Abbreviations: HB, hospital-based; HWE, Hardy-Weinberg equilibrium (in control); NOS, the Newcastle-Ottawa Scale; PB, population-based; PCR, polymerase chain reaction; PCR-RFLP, polymerase chain reaction and restriction fragment length polymorphism; PCR-SSP, polymerase chain reaction and sequence-specific primer.

\section{Quantitative synthesis}

Meta-analysis for IL-6 - I74G >C polymorphism with urinary system cancer

According to the inclusion criteria, 15 studies with 14,697 cases and 17,266 controls were analyzed. We conducted analyses using random-effects or fixed-effects model in overall population. As a result, we did not find any association between $I L-6-174 \mathrm{G}>\mathrm{C}$ polymorphism and urinary system cancer risk in overall population ( $\mathrm{G}$ vs $\mathrm{C}$ : $\mathrm{OR}=0.97,95 \%$ $\mathrm{CI}=0.89-1.05 ;$ GG vs CC: $\mathrm{OR}=0.89,95 \% \mathrm{CI}=0.75-1.06$;
GC vs CC: $\mathrm{OR}=0.92,95 \% \mathrm{CI}=0.79-1.07 ; \mathrm{GG}$ vs $\mathrm{GC}+\mathrm{CC}$ : $\mathrm{OR}=1.00,95 \% \mathrm{CI}=0.96-1.05 ; \mathrm{GG}+\mathrm{GC}$ vs $\mathrm{CC}: \mathrm{OR}=0.91$, $95 \% \mathrm{CI}=0.79-1.06$, respectively). However, a certain association was found in Asian population ( $\mathrm{G}$ vs $\mathrm{C}$ : $\mathrm{OR}=0.81,95 \%$ $\mathrm{CI}=0.70-0.95 ; \mathrm{GG}$ vs CC: $\mathrm{OR}=0.51,95 \% \mathrm{CI}=0.35-0.74$; GC vs CC: $\mathrm{OR}=0.49,95 \% \mathrm{CI}=0.33-0.72 ; \mathrm{GG}+\mathrm{GC}$ vs CC: $\mathrm{OR}=0.50,95 \% \mathrm{CI}=0.35-0.72$, respectively). The same result was revealed by codominant model in subgroup of HWE (GG vs CC: OR $=0.83,95 \%$ CI $=0.69-0.99$ ). Meanwhile, we performed comprehensive analyses subclassified by 


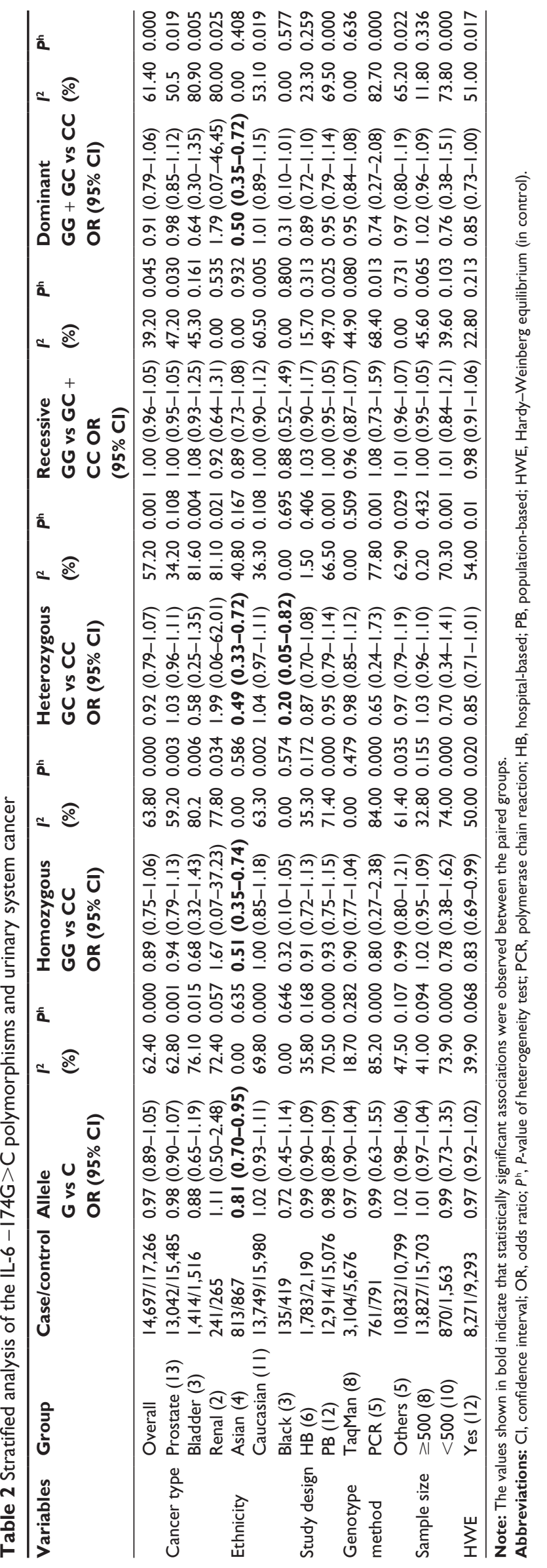

cancer types, control sources, genotyped methods, and the sample sizes, and eventually found no associations among each subgroup (Table 2).

\section{Meta-analysis for IL-6 -592G >C polymorphism with urinary system cancer}

The association between $I L-6-592 \mathrm{G}>\mathrm{C}$ polymorphism and urinary system cancer risk was assessed in seven studies with a total of 2,370 cases and 3,868 controls. Among which, six studies regarding PCa and one study regarding RCC were involved in the meta-analysis. As shown in Table 2, associations were observed in overall population ( $\mathrm{G}$ vs $\mathrm{C}$ : $\mathrm{OR}=0.1 .30,95 \% \mathrm{CI}=1.13-2.52$; GG vs $\mathrm{CC}: \mathrm{OR}=1.81$, $95 \% \mathrm{CI}=1.31-2.52 ; \mathrm{GG}$ vs $\mathrm{GC}+\mathrm{CC}: \mathrm{OR}=1.33,95 \%$ $\mathrm{CI}=1.02-1.75 ; \mathrm{GG}+\mathrm{GC}$ vs CC: $\mathrm{OR}=1.41,95 \% \mathrm{CI}=1.09-1.83)$. Besides, it seemed that there were some associations via subanalyses regarding cancer types, ethnicities, sources of control, genotyped methods, as well as sample sizes (Table 3).

\section{Meta-analysis for IL-6 -597G >A polymorphism with} urinary system cancer

Only four independent studies with 1,692 cases and 1,477 controls were included in such meta-analysis, including four studies upon PCa. The findings suggested no associations could be identified ( $\mathrm{G}$ vs $\mathrm{A}$ : $\mathrm{OR}=0.96,95 \%$ $\mathrm{CI}=0.87-1.07$; GG vs AA: OR $=0.92,95 \% \mathrm{CI}=0.74-1.15$; GA vs AA: OR $=0.93,95 \%$ CI $=0.77-1.14$; GG vs $\mathrm{GA}+$ AA: $\mathrm{OR}=0.97,95 \% \mathrm{CI}=0.82-1.15 ; \mathrm{GG}+\mathrm{GA}$ vs AA: $\mathrm{OR}=0.93,95 \% \mathrm{CI}=0.77-1.12$ ). Similarly, we did not find any association after comprehensive analyses conducted in aforementioned subgroups (Table 4).

\section{Sensitivity analysis}

One-way sensitivity analyses were individually performed by removing studies to assess the stability of the pooled results. Specifically, each single study included in the metaanalysis was deleted each time to observe the influence of the individual data to the pooled ORs, and none of which affected the pooled OR value, suggesting that the results of this meta-analysis were stable (Figure 2A-C).

\section{Evaluation of publication bias}

Begger's funnel plot revealed that no evidences of publication bias were found in different alleles of $I L-6$ polymorphisms $(I L-6-174 \mathrm{G}>\mathrm{C}: P=0.820 ; I L-6-592 \mathrm{G}>\mathrm{C}: P=0.881$; $I L-6-597 \mathrm{G}>\mathrm{A}: P=1.000$, Figure 3). Meanwhile, there was also no significant funnel asymmetry that could reveal publication bias in each subgroup meta-analysis (data not shown). 


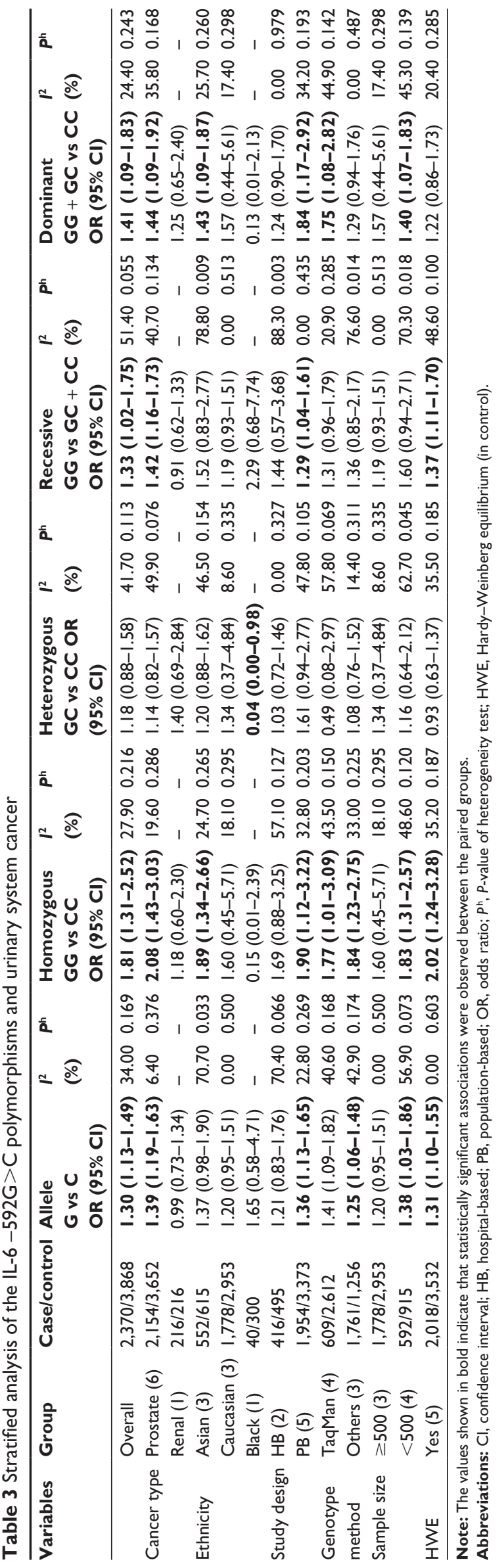

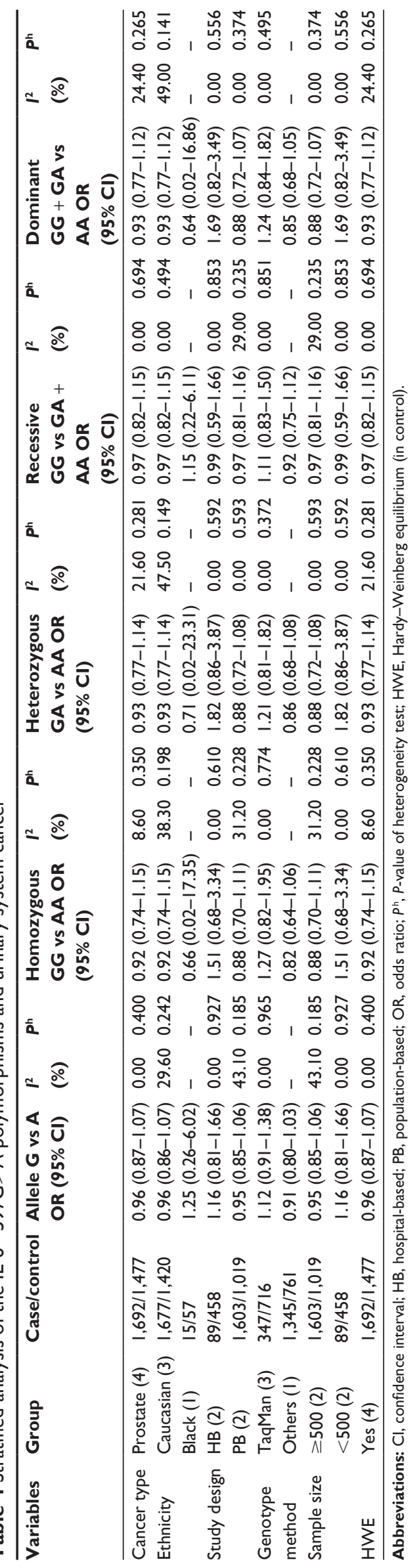




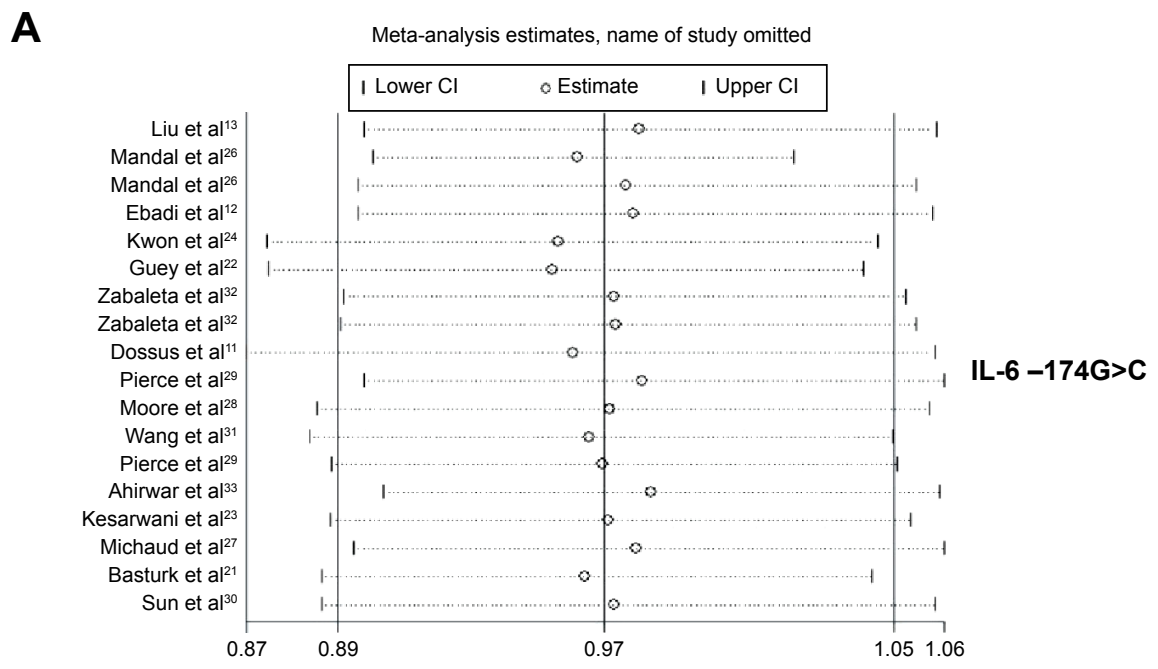

B

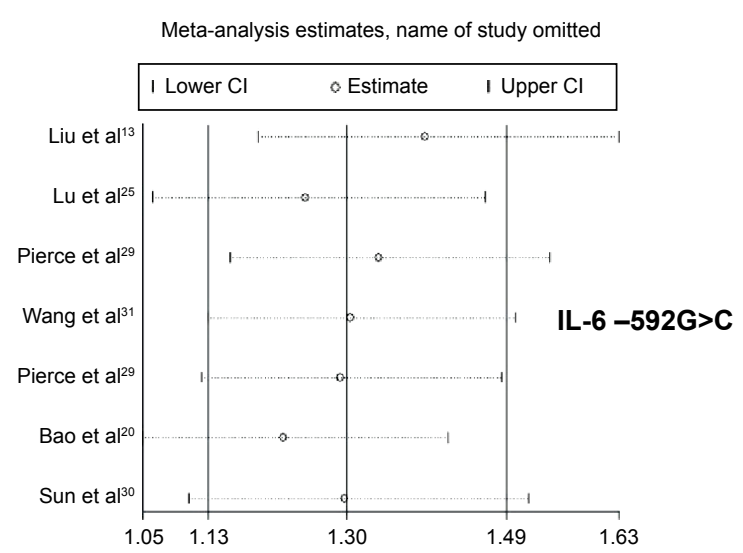

C

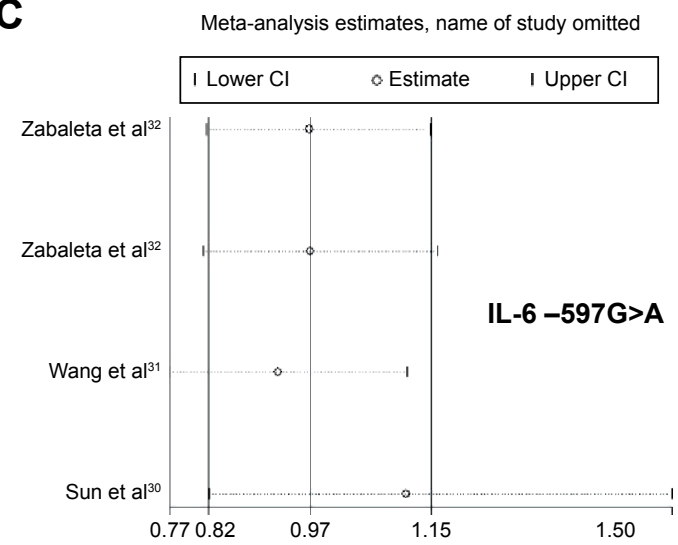

Figure 2 One-way sensitivity analysis of the IL-6 -174G >C (A), IL-6 -592G >C (B), and IL-6 -597G >A (C) polymorphisms with overall cancer risk. Abbreviations: $\mathrm{Cl}$, confidence interval; IL, interleukin.

\section{Discussion}

Until now, investigations focused on the associations between IL-6 polymorphisms and urinary system cancer risk were relatively rare and inconclusive. To the best of our knowledge, the current meta-analysis is a relatively detailed comprehensive summary to explore the associations between three $I L-6$ polymorphisms $(-174 \mathrm{G}>\mathrm{C},-592 \mathrm{G}>\mathrm{C}$, and $-597 \mathrm{G}>\mathrm{A})$ and urinary system cancers, including $\mathrm{PCa}, \mathrm{BCa}$, and $\mathrm{RCC}$. Meanwhile, further analyses were conducted in different subgroups to explore the potential associations. As a result, the current meta-analysis showed distinct associations between IL-6 -592G $>$ C polymorphisms and urinary system cancers in overall group and most of the subgroups. Intriguingly, no associations in overall population between $I L-6-174 \mathrm{G}>\mathrm{C}$ polymorphism and urinary system cancers were found. However, in the subgroup analysis of ethnicity, a linkage was solely confirmed in Asian population rather than any other. Meanwhile, no associations between $-592 \mathrm{G}>\mathrm{C}$ and urinary system cancers were detected in overall population and different subgroups, which results indicated that for certain population, cancer susceptibility may be associated with different genes, different loci within the same gene, or even different polymorphisms at the same locus. ${ }^{34}$

Recently, several published meta-analyses have paid much attention to explore the associations of $I L-6$ polymorphisms with various cancer types. On one hand, the associations seemed to be invalid. Concretely, $\mathrm{Yu}$ et $\mathrm{al}^{35}$ addressed that there was no association between a functional polymorphism $I L-6-174 \mathrm{G}>\mathrm{C}$ and breast cancer risk, regardless of the distinct ethnicities. Likewise, Wang et $\mathrm{al}^{36}$ showed that $I L-6-174 \mathrm{G}>\mathrm{C},-592 \mathrm{G}>\mathrm{C}$, and $-597 \mathrm{G}>\mathrm{A}$ polymorphisms were not associated with gastric cancer risk; subsequent subgroup analysis also did not explore any significant association in Asian or Caucasian population. Besides, no associations were found between $I L-6-174 \mathrm{G}>\mathrm{C}$ and lung cancer. ${ }^{37}$ On the other hand, some definite associations could be found between specific $I L-6$ polymorphisms and various cancer types. Based on the meta-analysis by Liu et al, ${ }^{38}$ $I L-6-174 \mathrm{G}>\mathrm{C}$, but not $I L-6-592 \mathrm{G}>\mathrm{C}$, polymorphism could be linked with hepatocellular carcinoma risk. In the 

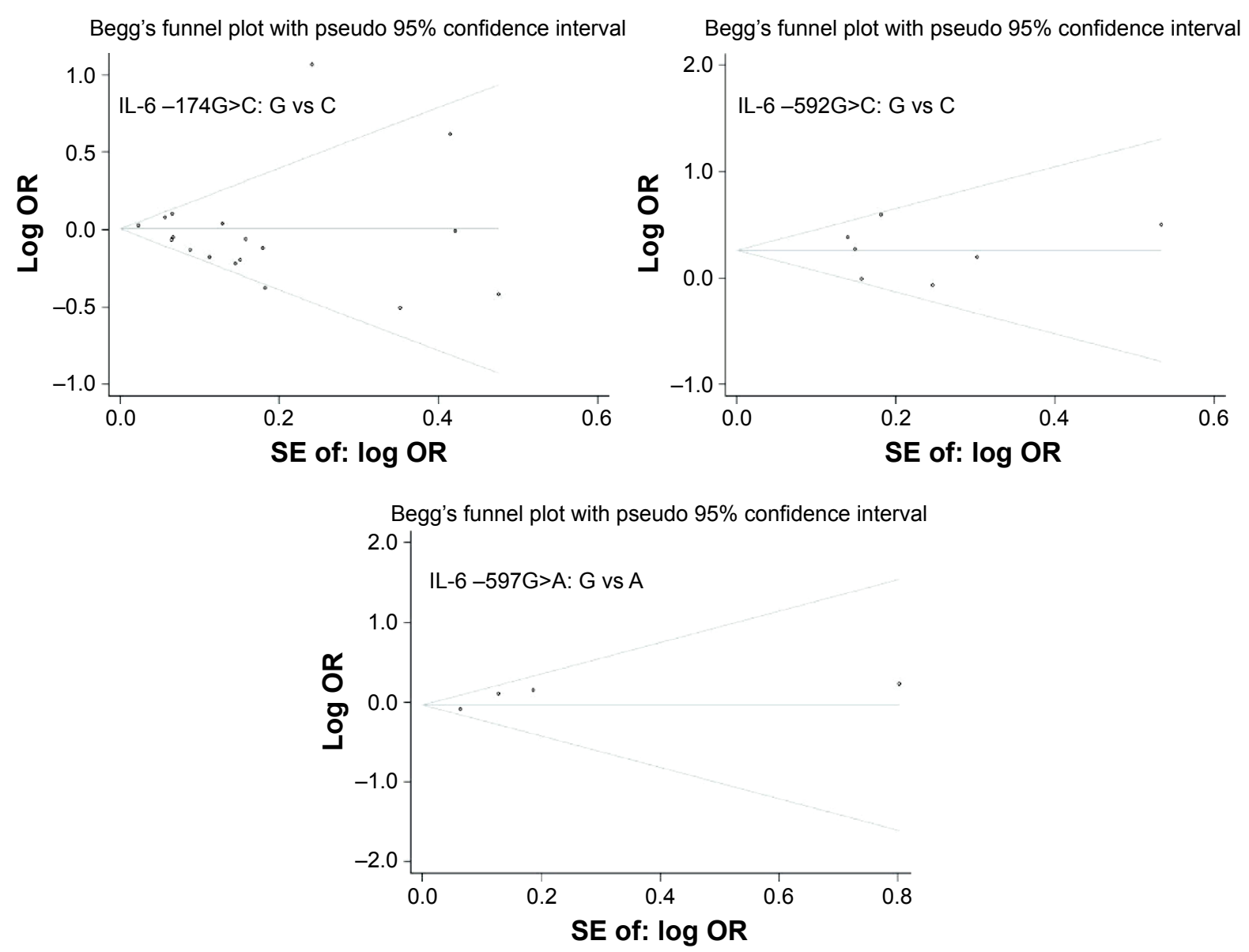

Figure 3 Begg's funnel plots to examine publication bias in different alleles of IL-6 polymorphisms.

Abbreviations: IL, interleukin; log OR, natural logarithm of OR; SE of: log OR, standard error of the log OR.

subgroup analysis of healthy population-based control and hepatocirrhosis population-based control, a significant association was detected between $-174 \mathrm{G}>\mathrm{C}$ polymorphism and hepatocellular carcinoma risk. For PCa, similar association with polymorphism was also confirmed. ${ }^{39}$ Besides, Joshi et $\mathrm{a}^{40}$ revealed associations between $I L-6-174 \mathrm{G}>\mathrm{C}$ polymorphism and genitourinary cancers risk in Ancestral North Indians. Notably, different $I L-6$ polymorphisms were probably associated with different cancer types, thus, we performed a relatively comprehensive meta-analysis simultaneously, including three $I L-6$ polymorphisms, three urinary system cancers, and corresponding subgroups in the current meta-analysis.

$I L-6$ gene is located on chromosome $7 \mathrm{p} 21-24$, whose promoter region contains several SNPs. It has been widely reported that $-174 \mathrm{G}>\mathrm{C},-592 \mathrm{G}>\mathrm{C}$, and $-597 \mathrm{G}>\mathrm{A}$ might show considerable impact on initiation and progression of cancer. Previous studies found that IL- 6 could go through a functional alternation from paracrine to autocrine growth factor in the development of cancer, especially for $\mathrm{PCa}^{41}$ and multiple myeloma. ${ }^{42}$ Concretely, IL- 6 acted as a paracrine growth factor on the hormone-sensitive lymph node carcinoma of prostate cells, while as an autocrine growth factor on the castration-resistant PC-3 PCa cells. ${ }^{43,44}$ Compared with healthy people or patients with localized cancer, IL-6 serum levels were increased in patients with distant bone metastasis or castration-resistant $\mathrm{PCa} .{ }^{45} \mathrm{IL}-6$ promoter haplotypes $(-174 \mathrm{G}>\mathrm{C},-592 \mathrm{G}>\mathrm{C}$, and $-597 \mathrm{G}>\mathrm{A}$ ) have shown significant effects on transcriptional regulation and disease association. ${ }^{46}$ Specifically, previous studies regarding the effect of $-174 \mathrm{G}>\mathrm{C}$ on transcription factor binding have shown that $-174 \mathrm{G}>\mathrm{C}$ transversion gates the GATA1 access to $I L-6$ promoter, thereby linking the SNPs to differential risk of inflammation-related diseases such as PCa. ${ }^{47}$ Accordingly, homozygotes for the $\mathrm{G}$ allele have been shown to have higher plasma levels of IL-6, higher $I L-6$ gene transcription activity, and higher inducible IL-6 responses compared with subjects homozygous for the $\mathrm{C}$ allele. In spite of that, there was evidence to support a positive association between $-174 \mathrm{G}$ allele and higher IL- 6 levels, $\mathrm{C}$ allele was essentially associated with $\mathrm{PCa} .{ }^{48} \mathrm{In}$ consideration of that, $-174 \mathrm{G}>\mathrm{C}$ and $-592 \mathrm{G}>\mathrm{C}$ possessed the identical alleles 
pattern, we speculated that the two polymorphisms might have similar effects on PCa. Integrating IL-6 with IL-6R could activate different signaling pathways of cancer, including the Janus tyrosine family kinase (JAK)-signal transducer and activator of transcription (STAT) pathway, the extracellular signal-regulated kinase 1 and 2 (ERK1/2)-mitogenactivated protein kinase pathway, and the phosphoinositide 3-kinase (PI3-K) and protein kinase B (PKB/Akt) pathway. ${ }^{49}$ In classic IL-6 signaling, upon binding of IL-6 to its receptor, JAK phosphorylates and activates STAT factors, a family of transcription factors. This allows dimerization of the STAT protein and subsequent exposition of its nuclear localization signal. STAT will then translocate to the nucleus for transcription initiation of downstream target genes. ${ }^{50}$ The targets of STAT-3 include growth factors and cytokines that are involved in inflammation-related carcinogenesis, such as hypoxia-inducible factor- $1 \alpha$, vascular endothelial growth factor, matrix metalloproteinase-2, and -9. A negative feedback loop exists for IL-6 through upregulation of suppressor of cytokine signaling 3 gene transcription by STAT-3. The suppressor of cytokine signaling 3 protein leads to termination of cytokine signaling through inhibition of JAK by direct binding to the kinases. ${ }^{50}$ IL- 6 also activates the ERK1/2-mitogen-activated protein kinase signaling pathway, JAK phosphorylates SHP2 (Src homology two domain-containing tyrosine phosphatase 2), a proteintyrosine phosphatase, which in turn leads to activation of Ras after IL-6 binding. This activation will subsequently trigger a cascade of events that result in successive elicitation of Raf, then mitogen-activated protein kinase kinase (MAPKK) and finally ERK..$^{50}$ In addition, IL-6 was addressed to be able to activate signal transduction through the PI3-K signaling pathway. When PI3-K is activated in response to ligand binding, the resulting second messenger recruits the protein kinase Akt to the plasma membrane and binds it with phosphorylation to translocate toward the nucleus and other subcellular components, where it regulates various biological processes, including anti-apoptosis and proliferation. ${ }^{50}$ In view of that, multiple lines of evidence supported an important role of genetics in determining cancer risk; understanding polymorphisms associated with cancer risk may be valuable for providing personalized diagnosis and therapy of certain cancers.

\section{Limitations}

There were several limitations in our meta-analysis. First, it was a retrospective study subjected to recall or selection bias of eligible studies in meta-analysis. Second, only published studies were included in current meta-analysis, which could not provide sufficient evidences to verify our findings, especially for the analysis of $\mathrm{BCa}$ and RCC. Finally, our result was performed by crude estimation; therefore, a more precise analysis would be needed to adjust whether the original data were available, such as smoking, drinking, gene-gene, and gene-environment interactions. Meanwhile, the heterogeneity of $I L-6$ polymorphism was relatively high, suggesting that there were potential and undiscovered factors in the included studies. Besides, some controls of eligible studies did not conform to HWE in this updated meta-analysis, which may influence the ultimate conclusion. All the limitations clearly require to be investigated in future research. In spite of the aforementioned limitations, this current meta-analysis has definitely shown noticeable associations between $I L-6$ polymorphisms and urinary system cancer risk.

\section{Conclusion}

This meta-analysis is a relatively detailed comprehensive study to explore the associations between the three $I L-6$ polymorphisms and urinary system cancer, including $\mathrm{PCa}$, $\mathrm{BCa}$, and $\mathrm{RCC}$. In summary, the current meta-analysis showed established associations between $I L-6-592 \mathrm{G}>\mathrm{C}$ polymorphisms and urinary system cancer in overall group and most of the subgroups. In the almost whole subgroup of Asian population, a marginally significant association was explored between urinary system cancer and $I L-6-174 \mathrm{G}>\mathrm{C}$ polymorphism rather than $-597 \mathrm{G}>\mathrm{A}$, which also validates that chronic inflammation may be a potential risk factor in urinary system cancer. A more well-designed prospective study based on large sample size, multiple SNPs, or haplotypes is needed to confirm the current findings.

\section{Acknowledgments}

This meta-analysis was supported by grants from the National Natural Science Foundation of China (81370856, 81170698, 81401518), Anhui Provincial Natural Science Foundation (1408085QH180), and the cultivation project for National Natural Science Foundation of China at Anhui Medical University (2013KJ14). The funders had no role in study design, data collection and analysis, decision to publish, or preparation of the manuscript.

\section{Disclosure}

The authors report no conflicts of interest in this work.

\section{References}

1. Siegel RL, Miller KD, Jemal A. Cancer statistics, 2015. CA Cancer J Clin 2015;65(1):5-29.

2. He Y, Yue Y, Zheng X, Zhang K, Chen S, Du Z. Curcumin, inflammation, and chronic diseases: How are they linked? Molecules. 2015;20(5): 9183-9213. 
3. Taverna G, Pedretti E, Di Caro G, Borroni EM, Marchesi F, Grizzi F. Inflammation and prostate cancer: friends or foe? Inflamm Res. 2015;64(5): 275-286.

4. Hirao Y, Kim WJ, Fujimoto K. Environmental factors promoting bladder cancer. Curr Opin Urol. 2009;19(5):494-499.

5. Winn SK, Ellis S, Savage P, Sampson S, Marsh JE. Biopsy-proven acute interstitial nephritis associated with the tyrosine kinase inhibitor sunitinib: a class effect? Nephrol Dial Transplant. 2009;24(2):673-675.

6. Phoa N, Epe B. Influence of nitric oxide on the generation and repair of oxidative DNA damage in mammalian cells. Carcinogenesis. 2002; 23(3):469-475.

7. Culig Z, Steiner H, Bartsch G, Hobisch A. Interleukin-6 regulation of prostate cancer cell growth. J Cell Biochem. 2005;95(3):497-505.

8. Berger FG. The interleukin-6 gene: a susceptibility factor that may contribute to racial and ethnic disparities in breast cancer mortality. Breast Cancer Res Treat. 2004;88(3):281-285.

9. Yu Y, Wang W, Zhai S, Dang S, Sun M. IL6 gene polymorphisms and susceptibility to colorectal cancer: a meta-analysis and review. Mol Biol Rep. 2012;39(8):8457-8463.

10. Zheng X, Han C, Shan R, et al. Association of interleukin-6 polymorphisms with susceptibility to hepatocellular carcinoma. Int J Clin Exp Med. 2015;8(4):6252-6256.

11. Dossus L, Kaaks R, Canzian F, et al. PTGS2 and IL6 genetic variation and risk of breast and prostate cancer: results from the Breast and Prostate Cancer Cohort Consortium (BPC3). Carcinogenesis. 2010;31(3): 455-461.

12. Ebadi N, Jahed M, Mivehchi M, Majidizadeh T, Asgary M, Hosseini SA. Interleukin-12 and interleukin-6 gene polymorphisms and risk of bladder cancer in the Iranian population. Asian Pac J Cancer Prev. 2014;15(18):7869-7873.

13. Liu Z, Wang Z, Xiao Y, Lu Y, Lu Y. Association between the interleukin-6 gene polymorphisms and renal cancer risk. Immunol Lett. 2015;164(2): $125-128$.

14. Munafo MR, Flint J. Meta-analysis of genetic association studies. Trends Genet. 2004;20(9):439-444.

15. Stang A. Critical evaluation of the Newcastle-Ottawa scale for the assessment of the quality of nonrandomized studies in meta-analyses. Eur J Epidemiol. 2010;25(9):603-605.

16. Higgins JP, Thompson SG. Quantifying heterogeneity in a metaanalysis. Stat Med. 2002;21(11):1539-1558.

17. DerSimonian R, Laird N. Meta-analysis in clinical trials. Control Clin Trials. 1986;7(3):177-188.

18. Mantel N, Haenszel W. Statistical aspects of the analysis of data from retrospective studies of disease. J Natl Cancer Inst. 1959;22(4):719-748.

19. Begg CB, Berlin JA. Publication bias and dissemination of clinical research. J Natl Cancer Inst. 1989;81(2):107-115.

20. Bao S, Yang W, Zhou S, Ye Z. Relationship between single nucleotide polymorphisms in $-174 \mathrm{G} / \mathrm{C}$ and $-634 \mathrm{C} / \mathrm{G}$ promoter region of interleukin-6 and prostate cancer. J Huazhong Univ Sci Technolog Med Sci. 2008;28(6):693-696.

21. Basturk B, Yavascaoglu I, Vuruskan H, Göral G, Oktay B, Oral HB. Cytokine gene polymorphisms as potential risk and protective factors in renal cell carcinoma. Cytokine. 2005;30(1):41-45.

22. Guey LT, Garcia-Closas M, Murta-Nascimento C, et al. Genetic susceptibility to distinct bladder cancer subphenotypes. Eur Urol. 2010;57(2): 283-292.

23. Kesarwani P, Ahirwar DK, Mandhani A, Mittal RD. Association between $-174 \mathrm{G} / \mathrm{C}$ promoter polymorphism of the interleukin- 6 gene and progression of prostate cancer in North Indian population. DNA Cell Biol. 2008;27(9):505-510.

24. Kwon EM, Salinas CA, Kolb S, et al. Genetic polymorphisms in inflammation pathway genes and prostate cancer risk. Cancer Epidemiol Biomarkers Prev. 2011;20(5):923-933.

25. Lu XM, Hua LX, Wang JF. Association of IL-6 $-572 \mathrm{C}>\mathrm{G}$ polymorphism with the susceptibility to prostate cancer in the Chinese Han population in Jiangsu and Anhui area. Zhonghua Nan Ke Xue. 2011;17(8): $707-711$.
26. Mandal S, Abebe F, Chaudhary J. -174G/C polymorphism in the interleukin-6 promoter is differently associated with prostate cancer incidence depending on race. Genet Mol Res. 2014;13(1):139-151.

27. Michaud DS, Daugherty SE, Berndt SI, et al. Genetic polymorphisms of interleukin-1B (IL-1B), IL-6, IL-8, and IL-10 and risk of prostate cancer. Cancer Res. 2006;66(8):4525-4530.

28. Moore SC, Leitzmann MF, Albanes D, et al. Adipokine genes and prostate cancer risk. Int J Cancer. 2009;124(4):869-876.

29. Pierce BL, Biggs ML, DeCambre M, et al. C-reactive protein, interleukin-6, and prostate cancer risk in men aged 65 years and older. Cancer Causes Control. 2009;20(7):1193-1203.

30. Sun J, Hedelin M, Zheng SL, et al. Interleukin-6 sequence variants are not associated with prostate cancer risk. Cancer Epidemiol Biomarkers Prev. 2004;13(1):10-15.

31. Wang MH, Helzlsouer KJ, Smith MW, et al. Association of IL10 and other immune response- and obesity-related genes with prostate cancer in CLUE II. Prostate. 2009;69(8):874-885.

32. Zabaleta J, Su LJ, Lin HY, et al. Cytokine genetic polymorphisms and prostate cancer aggressiveness. Carcinogenesis. 2009;30(8):1358-1362.

33. Ahirwar D, Kesarwani P, Manchanda PK, Mandhani A, Mittal RD. Anti- and proinflammatory cytokine gene polymorphism and genetic predisposition: association with smoking, tumor stage and grade, and bacillus Calmette-Guerin immunotherapy in bladder cancer. Cancer Genet Cytogenet. 2008;184(1):1-8.

34. Ju W, Kim JW, Park NH, et al. Matrix metalloproteinase-1 promoter polymorphism and epithelial ovarian cancer: does ethnicity matter? J Obstet Gynaecol Res. 2007;33(2):155-160.

35. Yu KD, Di GH, Fan L, Chen AX, Yang C, Shao ZM. Lack of an association between a functional polymorphism in the interleukin-6 gene promoter and breast cancer risk: a meta-analysis involving 25,703 subjects. Breast Cancer Res Treat. 2010;122(2):483-488.

36. Wang J, He W, Liu J, Nong L, Wei Y, Yang F. Association of IL-6 polymorphisms with gastric cancer risk: evidences from a meta-analysis. Cytokine. 2012;59(1):176-183.

37. Jiao F, Xu D, Li Q, Liu G, Liu H, Ren T. Lack of association between $-174 \mathrm{G}>\mathrm{C}$ and $-634 \mathrm{C}>\mathrm{G}$ polymorphisms in interleukin-6 promoter region and lung cancer risk: a meta-analysis. Tumour Biol. 2014;35(5):5021-5027.

38. Liu Y, Gao SJ, Du BX, Wang JJ. Association of IL-6 polymorphisms with hepatocellular carcinoma risk: evidences from a meta-analysis. Tumour Biol. 2014;35(4):3551-3561.

39. Zhang H, Xu Y, Li L, Liu R, Ma B. The interleukin-6-174G/C polymorphism and prostate cancer risk: a systematic review and meta-analysis. Urol Int. 2012;88(4):447-453.

40. Joshi N, Kannan S, Kotian N, Bhat S, Kale M, Hake S. Interleukin $6-174 \mathrm{G}>\mathrm{C}$ polymorphism and cancer risk: meta-analysis reveals a site dependent differential influence in Ancestral North Indians. Hum Immunol. 2014;75(8):901-908.

41. Chung TD, Yu JJ, Spiotto MT, Bartkowski M, Simons JW. Characterization of the role of IL-6 in the progression of prostate cancer. Prostate. 1999;38(3):199-207.

42. Lauta VM. A review of the cytokine network in multiple myeloma: diagnostic, prognostic, and therapeutic implications. Cancer. 2003;97(10): 2440-2452.

43. Chang PC, Wang TY, Chang YT, et al. Autophagy pathway is required for IL-6 induced neuroendocrine differentiation and chemoresistance of prostate cancer LNCaP cells. PLoS One. 2014;9(2):e88556.

44. Mahon KL, Lin HM, Castillo L, et al. Cytokine profiling of docetaxelresistant castration-resistant prostate cancer. Br J Cancer. 2015;112(8): 1340-1348.

45. Adler HL, McCurdy MA, Kattan MW, Timme TL, Scardino PT, Thompson TC. Elevated levels of circulating interleukin- 6 and transforming growth factor-beta1 in patients with metastatic prostatic carcinoma. J Urol. 1999;161(1):182-187.

46. Cole SW, Arevalo JMG, Takahashi R, et al. Computational identification of gene-social environment interaction at the human IL6 locus. Proc Natl Acad Sci U S A. 2010;107(12):5681-5686. 
47. Tindall EA, Severi G, Hoang HN, et al. Interleukin-6 promoter variants, prostate cancer risk, and survival. Prostate. 2012;72(16):1701-1707.

48. Pereira DS, Garcia DM, Narciso FM, et al. Effects of 174 G/C polymorphism in the promoter region of the interleukin-6 gene on plasma IL-6 levels and muscle strength in elderly women. Braz J Med Biol Res. 2011;44(2):123-129.
49. Daniel PN, Jinyi L, Ashutosh KT. Inflammation and prostate cancer: the role of interleukin 6 (IL-6). BJU Int. 2014;113(6):986-992.

50. Heinrich PC, Behrmann I, Haan S, Hermanns HM, Müller-Newen G, Schaper F. Principles of interleukin (IL)-6-type cytokine signalling and its regulation. Biochem J. 2003;374(1):1-20.

\section{Publish your work in this journal}

OncoTargets and Therapy is an international, peer-reviewed, open access journal focusing on the pathological basis of all cancers, potential targets for therapy and treatment protocols employed to improve the management of cancer patients. The journal also focuses on the impact of management programs and new therapeutic agents and protocols on

\section{Dovepress}

patient perspectives such as quality of life, adherence and satisfaction. The manuscript management system is completely online and includes a very quick and fair peer-review system, which is all easy to use. Visit http://www.dovepress.com/testimonials.php to read real quotes from published authors.

Submit your manuscript here: http://www.dovepress.com/oncotargets-and-therapy-journal 